\title{
GENERALIZED STRUCTURAL EQUATION MODELLING: KEPUTUSAN PEMERIKSAAN HIV/AIDS PADA WARIA (ANALISIS DATA SURVEI TERPADU BIOLOGIS DAN PERILAKU TAHUN 2013)
}

\author{
Zita Atzmardina ${ }^{1}$, Indang Trihandini ${ }^{2}$ \\ ${ }^{1}$ Bagian Ilmu Kesehatan Masyarakat, Fakultas Kedokteran, Universitas Tarumanagara \\ ${ }^{2}$ Program Studi Ilmu Kesehatan Masyarakat, Fakultas Kesehatan Masyarakat, Universitas Indonesia \\ Email: zaatzt@gmail.com
}

Masuk : 10-03-2021, revisi: 28-04-2021, diterima untuk diterbitkan : 29-05-2021

\begin{abstract}
ABSTRAK
Waria sering mendapatkan diskriminasi. Perilaku waria yang berisiko perlu tindakan pendeteksian dini sehingga tidak menjadi sumber penularan. Penelitian bertujuan untuk melihat model perilaku waria dalam memutuskan pemeriksaan HIV/AIDS di Palembang, Pontianak, Samarinda, dan Makasar tahun 2013. Desain penelitian yang digunakan adalah cross sectional, menggunakan data STBP tahun 2013. Hasil analisis GSEM memperlihatkan faktor predisposing mempengaruhi keputusan pemeriksaan HIV/AIDS pada waria (koef. path=0,61). Peran petugas berpengaruh terhadap pengetahuan waria (koef. path=1,1) dan mempunyai pengaruh yang besar dalam pengambilan keputusan pemeriksaan HIV/AIDS pada waria (koef. path=3,5). Oleh sebab itu, penyuluhan melalui petugas kesehatan atau petugas lapangan sangat penting dalam pengambilan keputusan pemeriksaan HIV/AIDS.
\end{abstract}

Kata Kunci: GSEM, waria, pemeriksaan HIV/AIDS

\section{ABSTRACT}

Transvestites or shemales are usually discriminated. Their behavior is risky to be a contagious agent that can be prevented by having early detection. This study observes models of transvestite behavior in deciding to have HIV/AIDS screening test at Palembang, Pontianak, Samarinda and Makassar in 2013. The design was cross sectional. GSEM analysis result indicates that predisposing factor influences decision to have HIV/AIDS test on shemales (path coefficient $=0.61)$. Role of health officer effects knowledge of shemales $($ path coefficient $=1.1)$ and it has prominent impact on determination to have HIV/AIDS test on shemales (path coefficient $=3.5$ ). Therefore, socialization by health officer or field trainer is crucial on determining HIV/AIDS test.

Keywords: GSEM, transvestite, HIV/AIDS screening test

\section{PENDAHULUAN}

\section{Latar Belakang}

Peraturan undang-undang di Indonesia hanya menetapkan 2 gender saja, yaitu pria dan wanita, seperti ditafsir dari Undang-undang Perkawinan (UU No.1/1974) dan ketentuan serupa mengenai isi kartu penduduk yang ditetapkan dalam Undang-undang Administrasi Kependudukan (UU No. 23/2006). Peraturan Pemerintah No. 54/2007 tentang adopsi secara tegas menetapkan bahwa orang tua yang mengadopsi tidak boleh berupa pasangan homoseksual. Adopsi oleh orang yang belum kawin tidak diperbolehkan. Ketentuan ini menjadi masalah bagi orang transgender (USAID, 2013). Jika kita berbicara tentang waria, patut diketahui bahwa waria merupakan bagian dari kelompok LGBT. Waria juga dikenal dengan istilah transgender atau transeksual. Ada dua jenis transgender yaitu male to female (MTF) dan female to male (FTM), sehingga waria juga bisa disebut dengan istilah 'trans MTF' atau transwoman (Ariyanto, 2012).

Waria (wanita pria) yang berarti pria yang bersifat dan bertingkah laku seperti wanita atau pria yang mempunyai perasaan sebagai wanita (KBBI, 2012). Kelompok waria termasuk yang rentan atau rawan mengalami diskriminasi dan intoleransi, mereka tidak mempunyai kesempatan untuk mendapatkan pekerjaan di sektor formal, meskipun Undang-Undang Tenaga Kerja (No.13/2003) secara tegas melarang diskriminasi dalam bentuk apapun (USAID,2013). Lingkaran Survei 
Indonesia (LSI) mendapati bahwa 64,7 persen (2005) menjadi 80,6 persen (2012) dari 12.000 responden yang disurveinya merasa tidak nyaman hidup berdampingan dengan kelompok LGBT (Lestari, 2013).

HIV adalah virus yang melebahkan kekebalan tubuh manusia, artinya virus ini menyerang dan menghancurkan sistem kekebalan dalam tubuh manusia. Sistem kekebalan merupakan sistem pertahanan tubuh yang alami untuk melawan segala jenis infeksi dan bakteri (Unesco, 2009). Menurut catatan hingga 31 Maret 2006, jumlah kumulatif kasus HIV/AIDS di seluruh Indonesia ialah HIV 4332, AIDS 5822, semuanya 10.154. Kasus HIV/AIDS yang terbanyak di DKI Jakarta 3601, peringkat II Papua 1633, peringkat III Jawa Timur 1031. Di seluruh dunia lebih dari 40 juta orang terkena AIDS pada tahun 2004 (Budimulja, 2007). Hasil estimasi tahun 2009, di Indonesia terdapat 186.000 orang dengan HIV positif (Kemenkes, 2011). Cara penularan terutama melalui darah, cairan tubuh, dan hubungan seksual. Virus HIV ditemukan dalam jumlah besar dalam cairan sperma dan darah, sedangkan dalam jumlah kecilditemukan dalam air liur dan air mata (Budimulja, 2007).

Pencegahan HIV harus menjadi prioritas utama dalam kerangka respons nasional terhadap HIV/AIDS, di satu sisi dampak yang kompleks dari penyebaran virus HIV/AIDS, di satu sisi dampak yang kompleks dari penyebaran virus HIV di masyarakat harus dapat dimengerti dan ditindaklanjuti. Salah satu konsekuensi terburuk dari HIV/AIDS adalah stigma dan diskriminasi yang dihadapi para penderita atau mereka yang dinyatakan terinfeksi. Diskriminasi terhadap hal tersebut, mengakibatkan penderita yang telah sadar dengan kondisinya akan merahasiakan keadaannya, menarik diri dan terisolasi. Stigma ini juga hasil dari ketakutan yang tidak masuk akal tentang HIV. Oleh karena itu pendidikan tentang HIV dan AIDS dapat membantu mengurangi stigma tersebut (Kemendiknas, 2009).

Menurut teori perilaku dari Lawrence Green (Precede-Proceed Model), ada 3 kategori faktor yang dapat mempengaruhi perilaku individu atau kelompok yaitu Predisposing, Reinforcing, dan Enabling.

\section{Rumusan Masalah}

Menurut Kementrian Kesehatan, diskriminasi memaksa banyak waria menjadi pekerja seks, yang memicu kenaikan kasus HIV, yaitu dari enam menjadi 34 persen antara 1997 dan 2007 di kalangan waria di Jakarta. Menurut STBP tahun 2011, perilaku membeli seks paling banyak dilakukan oleh waria (26\%), begitu pula dengan perilaku menjual seks tertinggi dilakukan oleh waria (81\%). Meskipun menurut data $78 \%$ waria menyadari bahwa perilakunya bisa menyebabkan terjadi penularan HIV pada dirinya, tetapi mereka seringkali tidak mempunyai pilihan lain. Diketahui bahwa prevalensi HIV tertinggi terdapat pada penasun (41\%), diikuti waria $(22 \%)$. Sehingga dapat dilihat bahwa waria menduduki peringkat kedua, dan angkanya cukup tinggi.

Mayoritas waria adalah berpendidikan rendah yaitu tidak sekolah sampai dengan SMP. Sumber pendapatan utama waria adalah menjual seks dan bekerja di salon Pada tahun 2011, Waria yang memiliki pengetahuan komprehensif hanya $32 \%$, menurun dari $36 \%$ pada tahun 2009. Sebanyak $78 \%$ waria merasa bahwa dirinya merasa berisiko tertular. Dan hanya $60 \%$ waria yang pernah mendapatkan informasi dari petugas kesehatan (STBP, 2011). Tes HIV merupakan "pintu masuk" yang terpenting pada layanan pencegahan, perawatan, dukungan dan pengobatan. Tes dan konseling HIV (TKHIV) akan mendorong seseorang dan pasangan untuk mengambil langkah pencegahan penularan infeksi HIV (Kemenkes, 2013). Menurut data STBP tahun 2011, 
hanya $72 \%$ waria yang melakukan pemeriksaan HIV. Jumlah tersebut menurun menjadi 38,05 $\%$ di tahun 2013.

\section{METODE PENELITIAN}

Penelitian ini merupakan penelitian kuantitatif mengenai perilaku waria dalam mengambil keputusan melakukan pemeriksaan HIV/AIDS di 4 kota di Indonesia (Palembang, Pontianak, Samarinda, dan Makasar) pada tahun 2013 menggunakan data sekunder dari STBP Waria tahun 2013 oleh Kementrian Kesehatan RI. Desain penelitian menggunakan potong lintang (cross sectional). Populasi dalam penelitian ini adalah semua waria yang menjadi sampel pada STBP 2013 di 4 kota di Indonesia (Palembang, Pontianak, Samarinda, dan Makasar). Sampel dari penelitian ini adalah waria yang menjawab pertanyaan kuesioner dengan lengkap. Pengambilan sampel menggunakan tehnik Cluster Random Sampling, Jumlah sampel dalam penelitian ini sebesar 431 responden. Analisis yang digunakan adalah analisis univariabel dan analisis Generalized Structural Equation Modelling (GSEM).

Variabel yang digunakan terdiri dari variabel eksogen dan variabel endogen. Variabel eksogen yaitu faktor predisposing serta variabel endogen yaitu variabel faktor faktor reinforcing dan keputusan pemeriksaan HIV. Faktor predisposing terdiri dari umur, pendidikan, pengetahuan, pekerjaan, persepsi tentang risiko tertular. Faktor reinforcing terdiri dari kelompok pengguna narkoba dan peran petugas. Umur dihitung dari sejak lahir sampai waawancara STBP dilaksanakan yang terbagi dalam tujuh kategori (kurang dari19 tahun, 20-24 tahun, 25-29 tahun, 30-34 tahun, 35-39 tahun. 40-44 tahun, dan 45 tahun keatas). Tingkat pendidikan dilihat dari pendidikan formal tertinggi yang dicapai responden yang terbagi dalam tidak pernah sekolah dan SD/sederajat, SMP/sderajat, SMA/sederajat, dan akademi/perguruan tinggi. Pengetahuan komprehensif sesuai dengan indikator MDGs, yaitu menggunakan kondom dapat mencegah penularan HIV; setia dengan satu pasangan seks dapat mencegah penularan HIV; menggunakan alat makan bersama tidak menularkan HIV; gigitan nyamuk tidak menularkan HIV; dan tidak bisa mengenali ODHA hanya dengan melihat saja.

\section{HASIL DAN PEMBAHASAN}

Berdasarkan tabel 1, responden yang melakukan pemeriksaan HIV sebanyak 267 orang $(61,95$ $\%)$. Responden terbanyak berada direntang usia 25-29 tahun sebanyak 105 orang $(24,36 \%)$. Untuk tingkat pendidikan paling banyak memiliki tingkat pendidikan terakhir paling banyak SMU/sederajat sebanyak 258 orang $(59,86 \%)$. Responden yang memiliki pekerjaan yang berisiko sebanyak 339 orang $(78,65 \%)$. Persepsi bahwa responden memiliki risiko tertular atau tidak paling banyak responden yang mengatakan bahwa memiliki risiko tertular sebanyak 294 orang. Responden lebih banyak yang tidak memiliki pengetahuan komprehensif sebesar 69,14 $\%$, dengan jawaban benar terbanyak pada pengetahuan tentang penggunaan kondom dapat mencegah penularan HIV. Responden yang tidak mengkonsumsi napza sebanyak 336 orang (77,96\%) dan responden yang tidak pernah disarankan untuk melakukan pemeriksaan HIV sebanyak 280 orang $(64,97 \%)$

Tabel 1. Tabel Distribusi Frekuensi Waria (Analisis Data STBP 2013)

\begin{tabular}{lcc}
\hline Variabel & n & \% \\
\hline Keputusan Pemeriksaan HIV & & \\
$\quad$ Tidak & 164 & 38,05 \\
$\quad$ Ya & 267 & 61,95 \\
Umur & & \\
$\quad<19$ tahun & 23 & 5,34 \\
\hline
\end{tabular}




\begin{tabular}{|c|c|c|}
\hline Variabel & $\mathbf{n}$ & $\%$ \\
\hline $20-24$ tahun & 87 & 20,19 \\
\hline $25-29$ tahun & 105 & 24,36 \\
\hline $30-34$ tahun & 88 & 20,42 \\
\hline $35-39$ taun & 53 & 12,30 \\
\hline $40-44$ tahun & 40 & 9,28 \\
\hline$>45$ tahun & 35 & 8,12 \\
\hline \multicolumn{3}{|l|}{ Tingkat Pendidikan } \\
\hline$<\mathrm{SD} /$ sederajat & 44 & 10,21 \\
\hline SMP/sederajat & 94 & 21,81 \\
\hline SMU/sederajat & 258 & 59,86 \\
\hline Akademi/Perguruan tinggi & 35 & 8,12 \\
\hline \multicolumn{3}{|l|}{ Pekerjaan } \\
\hline Tidak Beresiko & 92 & 21,35 \\
\hline Berisiko & 339 & 78,65 \\
\hline \multicolumn{3}{|l|}{ Persepsi Risiko tertular } \\
\hline Tidak & 111 & 25,75 \\
\hline Tidak Tahu & 26 & 6,03 \\
\hline Ya & 294 & 68,21 \\
\hline \multicolumn{3}{|c|}{$\begin{array}{l}\text { Pengetahuan tentang menggunakan kondom } \\
\text { dapat mencegah penularan HIV }\end{array}$} \\
\hline Salah & 62 & 14,39 \\
\hline Benar & 369 & 85,61 \\
\hline \multicolumn{3}{|c|}{$\begin{array}{l}\text { Pengetahuan setia dengan satu pasangan seks } \\
\text { dapat mencegah penularan HIV }\end{array}$} \\
\hline Salah & 91 & 21,11 \\
\hline Benar & 340 & 78,89 \\
\hline \multicolumn{3}{|c|}{$\begin{array}{l}\text { Pengetahuan tentang menggunakan alat makan } \\
\text { bersama tidak menularkan HIV }\end{array}$} \\
\hline Salah & 139 & 32,25 \\
\hline Benar & 292 & 67,75 \\
\hline \multicolumn{3}{|c|}{$\begin{array}{l}\text { Pengetahuan tentang gigitan nyamuk tidak } \\
\text { menularkan HIV }\end{array}$} \\
\hline Salah & 155 & 35,96 \\
\hline Benar & 276 & 64,04 \\
\hline \multicolumn{3}{|c|}{$\begin{array}{l}\text { Pengetahuan tentang tidak bisa mengenali ODHA } \\
\text { hanya dengan melihat saja }\end{array}$} \\
\hline Salah & 138 & 32,02 \\
\hline Benar & 293 & 67,98 \\
\hline \multicolumn{3}{|l|}{ Pengetahuan Komprehensif } \\
\hline Tidak & 298 & 69,14 \\
\hline Ya & 133 & 30,86 \\
\hline \multicolumn{3}{|l|}{ Konsumsi Napza } \\
\hline Tidak & 336 & 77,96 \\
\hline $\mathrm{Ya}$ & 95 & 22,04 \\
\hline \multicolumn{3}{|l|}{ Peran Petugas } \\
\hline Tidak pernah & 280 & 64,97 \\
\hline Pernah & 151 & 35,03 \\
\hline Total & 431 & 100 \\
\hline
\end{tabular}


Analisis Generalized Structural Equation Modelling (GSEM) terdiri dari beberapa tahapan yaitu, spesifikasi model awal, identifikasi model, estimasi model keseluruhan, respesifikasi model, dan model persamaan struktural.

Spesifikasi model awal pada gambar 1 memperlihatkan konsep penelitian yang akan dilakukan. Pada penelitian ini terdapat tiga buah variabel laten yang terdiri dari dua variabel endogen yaitu variabel faktor faktor reinforcing dan keputusan pemeriksaan HIV, serta satu variabel eksogen yaitu faktor predisposing.Variabel teramati pembentuk variabel laten secara keseluruhan berjumlah 8 variabel. Confirmatory factor analysis (CFA) dilakukan untuk mendapatkan variabel yang dapat diikutsertakan dalam analisis GSEM dengan syarat nilai koefisien jalur tersebut signifikan (nilai $\mathrm{p} \leq 0,05$ ).

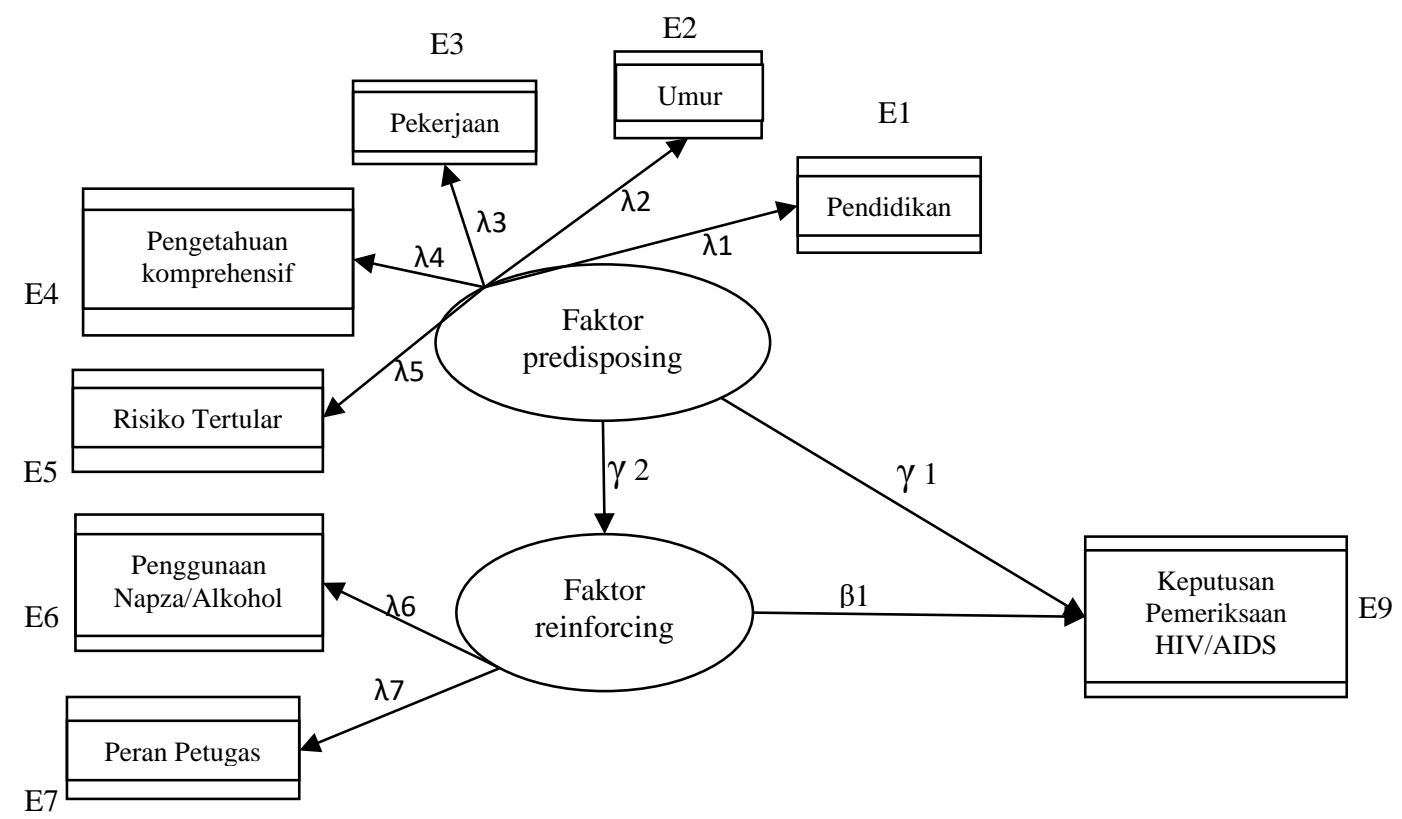

\section{Gambar 1. Model Awal Keputusan Pemeriksaan HIV/AIDS}

Gambar 2 menunjukkan bahwa variabel yang mempunyai pengaruh terbesar terhadap pemeriksaan HIV/AIDS adalah variabel predisposing (koefisien 2,7). Kemudian loading factor pada masing-masing variabel laten juga cukup kuat yaitu > 0,05 yang artinya semua variabel laten valid untuk membentuk variabel keputusan pemeriksaan HIV/AIDS. Meskipun telah dilakukan 50 iterasi, model ini belum konvergen, sehingga dilakukan respesifikasi model untuk tahap berikutnya, dengan melihat nilai kemaknaannya. Dari hasil yang didapat, yang memiliki nilai $\mathrm{P}$ terbesar untuk faktor predisposing adalah pendidikan dan untuk faktor reinforcing adalah penggunaan napza, maka variabel pendidikan dikeluarkan dari model, dan ternyata masih belum fit, maka selanjutnya variabel penggunaan napza dikeluarkan dari model. Ternyata, setelah dilakukan iterasi sebanyak 50 kali, model masih belum fit, maka dilakukan dengan mencoba menghubungkan masing-masing variabel teramati. 


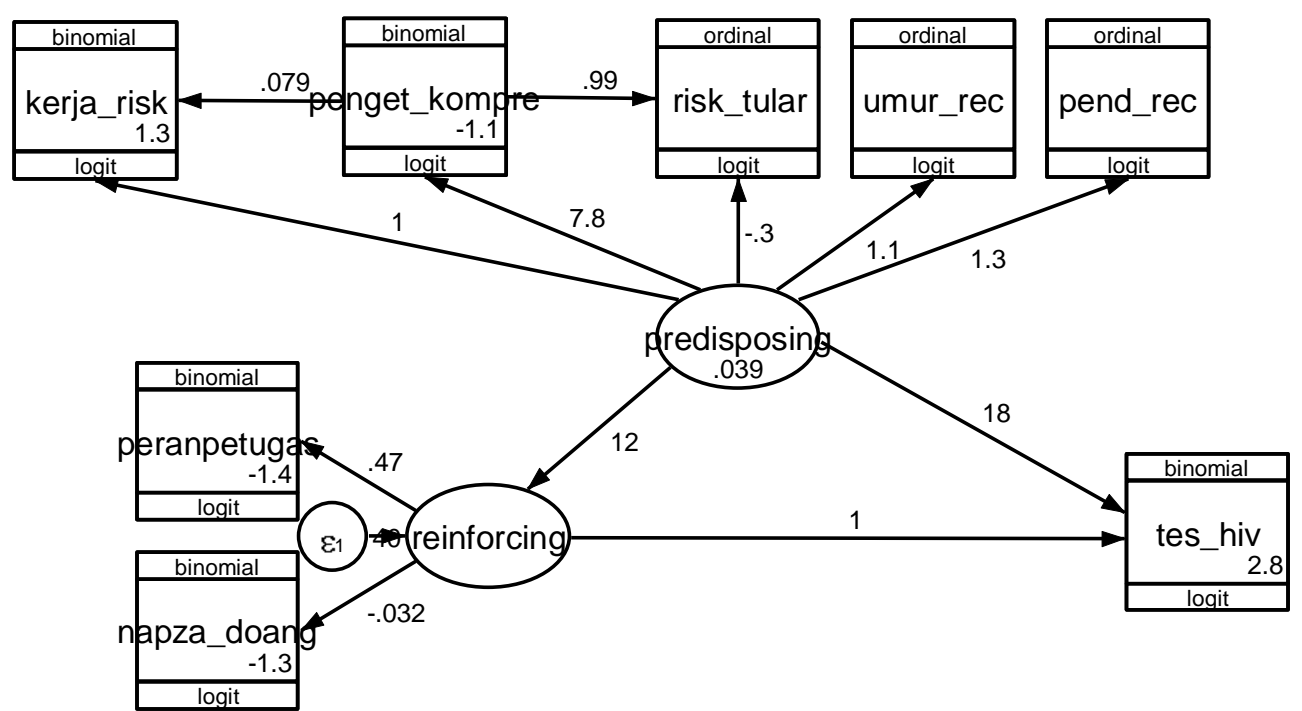

Gambar 2. Estimasi Model Awal Keputusan Pemeriksaan HIV/AIDS

Dari gambar 3 yang merupakan hasil respesifikasi model menunjukkan bahwa variabel yang mempunyai pengaruh terbesar terhadap pemeriksaan HIV/AIDS adalah variabel teramati peran petugas (koefisien 3,5) dibandingkan dengan faktor predisposing dan penggunaan kondom. Kemudian loading factor pada masing-masing variabel juga cukup kuat yaitu > 0,05 yang artinya semua variabel laten valid untuk membentuk variabel keputusan pemeriksaan HIV/AIDS.

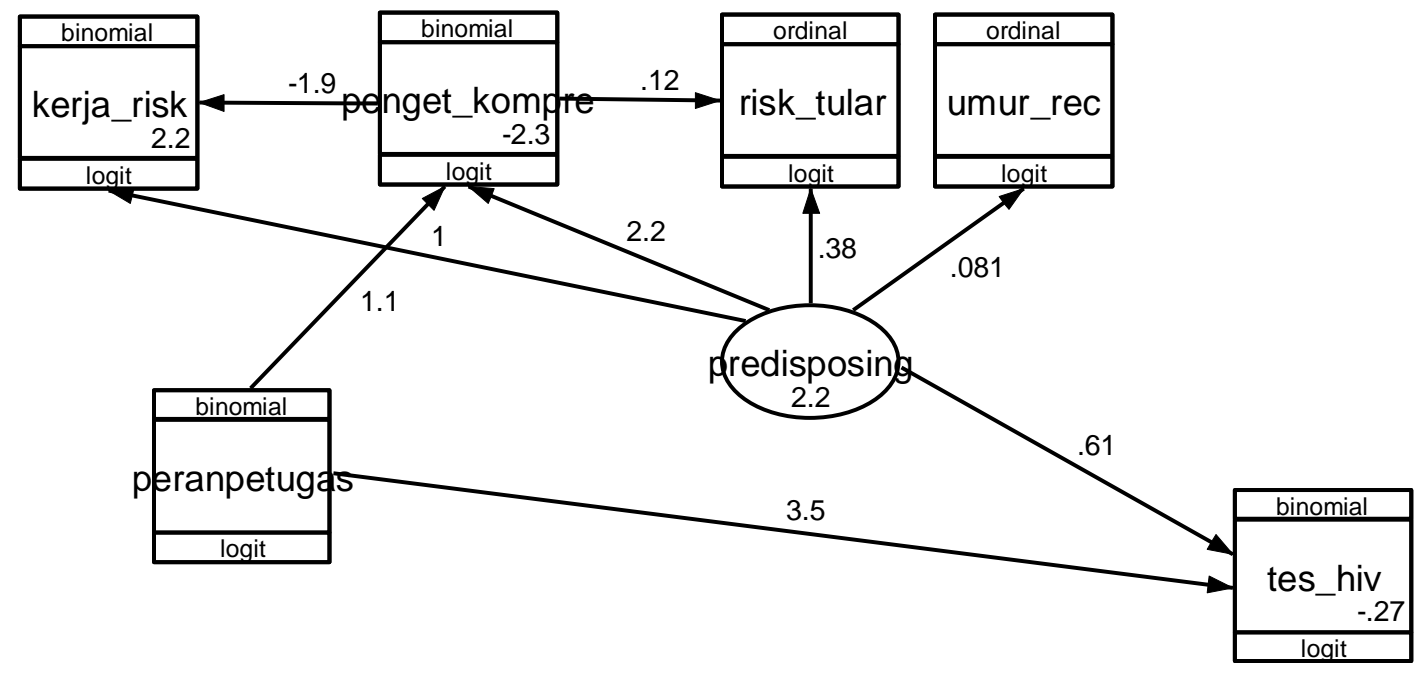

Gambar 3. Model Akhir Keputusan Pemeriksaan HIV/AIDS

Penelitian ini tentang faktor predisposing yang terdiri dari karakteristik, pengetahuan dan persepsi responden berhubungan dengan keputusan pemeriksaan HIV/AIDS. Dalam penelitian ini faktor predisposing memberi pengaruh terhadap keputusan pemeriksaan HIV/AIDS dengan koef path=0,61. Hal tersebut juga sesuai dengan hasil penelitian yang dilakukan oleh Wahyuddin tahun 2010 menunjukkan bahwa faktor-faktor dalam diri yang mempengaruhi keputusan waria dalam melakukan tes HIV/AIDS adalah karekteristik responden dan pengalaman waria itu sendiri. 
Sebanyak 164 orang $(38,05 \%)$ tidak melakukan pemeriksaan HIV. Semakin tinggi usia seseorang, pengalaman yang didapat akan semakin banyak. Dalam penelitian ini didapatkan bahwa semakin tinggi usia waria tersebut maka kesadaran untuk melakukan tes HIV meningkat sekitar dua kali lipat untuk setiap kelompok umur. Hal ini tidak sesuai dengan hasil penelitian yang dilakukan oleh I Gusti Ayu Ary (2014) bahwa tidak ada hubungan antara usia dengan perilaku pemeriksaan VCT. Tingkat Pendidikan paling banyak SMU/sederajat sebanyak 258 (59,86\&). Meskipun tingkat pendidikan sudah cukup baik, namun tingkat pengetahuannya masih cukup kurang yaitu sebanyak 298 orang $(69,14 \%)$ tidak memiliki pengetahuan yang komprehensif.

Pengetahuan tentang penggunaan kondom dan setia dengan satu pasangan dapat mencegah penularan HIV cukup baik yaitu sebanyak 369 orang $(85,61 \%)$ mengetahui bahwa penggunaan kondom dapat mencegah penularan HIV dan sebanyak 340 orang $(78,89 \%)$ mengetahui bahwa setia dengan satu pasangan seks dapat mencegah penularan HIV, meskipun begitu tetapi masih banyak waria yang memilih pekerjaan yang beresiko yaitu sebanyak 339 orang (78,65 \%). Waria juga mengetahui bahwa mereka memiliki persepsi bahwa mereka merasa dirinya tertular. Sebanyak 294 orang $(68,21 \%)$ merasa dirinya beresiko tertular, meskipun begitu banyak waria yang tidak mempunyai pilihan lain sehingga 339 orang $(78,65 \%)$ memilih pekerjaan yang berisiko.

Waria termasuk kelompok yang tidak menggunakan narkoba. Hal ini dapat dilihat bahwa sebanyak 336 orang $(77,96 \%)$ tidak mengkonsumsi napza. Ini merupakan hal yang positif dari waria. Pengetahuan yang diuji disini adalah pengetahuan komprehensif yang terdiri dari menggunakan kondom dapat mencegah penularan HIV, setia dengan satu pasangan seks dapat mencegah penularan HIV, menggunakan alat makan bersama tidak menularkan HIV, gigitan nyamuk tidak menularkan HIV, dan tidak bisa mengenali ODHA hanya dengan melihat saja. Dalam membentuk keputusan di model akhir, pengetahuan memiliki koefisien yang paling tinggi (koef path=2,2) dalam membentuk variabel laten, dalam hal ini faktor predisposing. Karena itu pengetahuan memiliki peranan yang sangat penting dalam keputusan pemeriksaan HIV/AIDS.

Dalam penelitian ini, pada model akhir, variabel teramati pengetahuan, memberikan pengaruh terhadap pekerjaan waria apakah berisiko atau tidak (koef path=-1,9) serta persepsi atau keyakinan responden apakah dirinya merasa tertular atau tidak (koef path=0.12). Koefisien path pengetahuan terhadap pekerjaan beresiko ini memiliki nilai yang negatif, berarti bahwa semakin tinggi pengetahuan seseorang, maka keputusan semakin kecil memutuskan untuk melakukan pekerjaan yang beresiko. Sedangkan koefisien path pengetahuan terhadap persepsi responden memiliki nilai yang positif, hal ini berarti bahwa semakin tinggi pengetahuan waria, maka persepsi waria bahwa pekerjaannya memiliki risiko semakin baik.

Kalau kita lihat, peran petugas berpengaruh terhadap pengetahuan komprehensif waria (koef path=1,1), hal ini berarti semakin besar peran petugas tersebut, maka semakin tinggi juga pengetahuan waria. Peran petugas juga secara langsung berpengaruh yang cukup besar terhadap keputusan pemeriksaan HIV/AIDS (koef path=3,5), hal ini berarti semakin tinggi peran petugas terhadap waria, maka semakin tinggi juga tingkat kesadaran waria untuk melakukan pemeriksaan HIV/AIDS. Hal ini juga sejalan dengan penelitian yang dilakukan oleh yang mengungkapkan bahwa dukungan kelompok sebaya yang dirasakan cukup efektif dalam mempengaruhi perilaku waria dalam pencarian pengobatan dan juga penelitian yang dilakukan oleh Ayu Indriani L (2012) bahwa Klien VCT yang datang ke klinik VCT sebagian besar atas rujukan dokter. 
Pengetahuan merupakan salah satu faktor yang penting dan karena peran petugas disini memberikan pengaruh yang positif terhadap pengetahuan waria itu sendiri, maka sebaiknya dinas kesehatan atau LSM sering memberikan penyuluhan baik secara langsung maupun tidak langsung kepada waria yang juga sebagai salah satu program mendeteksi dini yang seharusnya diberikan secara tepat, kreatif, dan menarik, baik dari sisi materi maupun dari sisi metode penyampaiannya, dan berkelanjutan. Penyuluhan mengenai HIV/AIDS pada waria perlu dilakukan secara intensif dan tepat sasaran, sehingga waria dapat segera menyadari bahwa perilakunya merupakan perilaku yang berisiko. Penyuluhan sebaiknya juga dilakukan secara berkala, karena penyuluhan yang berkala, dapat memberikan dampak positif terhadap perubahan perilaku individu itu sendiri.

Program-program yang baik juga diperlukan guna meningkatkan kesadaran waria dalam melakukan pemeriksaan HIV/AIDS. Karena itu sebaiknya Dinas Kesehatan atau instansi terkait mengadakan pembinaan dan pelatihan terhadap tenaga kesehatan yang bertugas di lapangan maupun petugas lapangan yang lain, sehingga tenaga kesehatan dan petugas lapangan mempunyai kemampuan yang lebih baik dalam memberikan pengaruh yang positif kepada waria.

Berdasarkan hasil penelitian ini, peran petugas memiliki koefisien yang cukup tinggi, sehingga petugas sebaiknya dapat memberikan penyuluhan dan pendekatan kepada waria. Tetapi pada kenyataanya , meskipun waria telah mengerti penjelasan petugas, namun masih banyak perilaku waria yang menyimpang oleh karena mereka nurut kepada atasannya, dalam hal ini mucikari (atau dikenal dengan sebutan "mami"), karena itu sebaiknya petugas juga memberikan penyuluhan dan pendekatan kepada mucikari atau "mami" sehingga para mucikari atau "mami" tersebut dapat memberikan dampak yang positif kepada waria tersebut.

Peran dari petugas memiliki peran yang sangat penting, maka penulis menyarankan agar diadakan penjangkauan pelayanan kesehatan seperti tes HIV dan konseling yang lebih luas terhadap waria dengan teknik snowball (jemput bola) yaitu dengan mendatangi mereka ke tempat mereka biasa berkumpul bersama kelompoknya karena waria juga merupakan kelompok yang agak sulit untuk dijangkau atau dengan mengintegrasikan kedua layanan tersebut di puskesmas atau klinik swasta. Dengan demikian, waria yang tertutup banyak pula yang terjangkau oleh program tersebut. Layanan Pemeriksaan HIV/AIDS yang sudah ada juga harus memberikan dukungan medis kepada waria sehingga dapat terus berjalan dan menjangkau semua waria.

Kenyamanan dan kepuasan dari waria juga harus diperhatikan, sehingga waria mrasa nyaman dalam melakukan pemeriksaan, karena itu disarankan agar pihak terkatit dapat juga membuat tempat pelayanan kesehatan yang terjangkau agar waria selalu mendapatkan pelayanan yang baik sehingga dapat selalu memeriksakan kondisi kesehatannya tanpa merasa terasingkan. Menurut penelitian yang dilakukan oleh Nur Hidaya, et all mengatakan sikap baik petugas membuat waria merasa nyaman menerima layanan dan memotivasi mereka untuk tetap menggunakan layanan yang tersedia.

Waria memang dianggap sebagai kelompok masyarakat yang mempunyai perilaku yang tidak seperti manusia normal, tetapi mereka punya hak untuk diperlakukan sebagai manusia normal dan punya hak untuk mendapatkan pelayanan kesehatan yang baik seperti masyarakat lainnya. Karena itu sudah sebaiknya pemerintah memfasilitasi hak waria tersebut sehingga waria bisa mendapatkan hak yang lebih baik. 


\section{KESIMPULAN DAN SARAN}

Hasil penelitian yang telah dilakukan pada 202 responden waria di Palembang, Pontianak, Samarinda, dan Makasar tahun 2013 dapat diambil kesimpulan sebagai berikut:

1. Sebanyak $61,95 \%$ responden pernah melakukan pemeriksaan HIV/AIDS.

2. Variabel pengetahuan memiliki pengaruh yang paling besar dalam membentuk variabel laten predisposing (koef path=2,2)

3. Faktor predisposing mempengaruhi keputusan pemeriksaan HIV/AIDS dengan koef path $=0,61$

4. Faktor reinforcing, dalam hal ini peran petugas dapat secara langsung mempengaruhi pengambilan keputusan melakukan pemeriksaan HIV/AIDS (koef path $=3,5$ ).

Berdasarkan hasil penelitian yang telah dilakukan, maka penulis berpendapat bahwa masih diperlukan program-program guna meningkatkan kesadaran waria dalam melakukan pemeriksaan HIV/AIDS.

A. Bagi Kementerian Kesehatan dan Dinas Kesehatan

1. Layanan Pemeriksaan HIV/AIDS yang sudah ada harus memberikan dukungan medis kepada waria sehingga dapat terus berjalan dan menjangkau semua waria.

2. Kebijakan pelayanan kesehatan untuk kelompok berisiko seperti waria, sebaiknya bersifat inklusif, sesuai dengan kode etik medis dan kesehatan. Pelayanan yang inklusif memiliki arti pelayanan yang sama untuk semua populasi baik populasi umum maupun populasi beresiko

3. Kementrian Kesehatan perlu meningkatkan kualitas data survei STBP 2013 khususnya mengenai penularan HIV/AIDS di kalangan waria, seperti dalam hal teknik pengambilan sampel dan alat ukur, sehingga dapat menjangkau seluruh waria dan didapatkan informasi yang lebih baik. Dengan demikian, data tersebut dapat digunakan dalam penelitian-penelitian berikutnya dan untuk melakukan analisis lanjutan.

\section{B. Bagi Dinas Kesehatan}

1. Perlu adanya penjangkauan pelayanan kesehatan seperti tes HIV dan konseling yang lebih luas terhadap waria dengan teknik snowball (jemput bola) yaitu dengan mendatangi mereka ke tempat mereka biasa berkumpul bersama kelompoknya karena waria juga merupakan kelompok yang agak sulit untuk dijangkau atau dengan mengintegrasikan kedua layanan tersebut di puskesmas atau klinik swasta. Dengan demikian, waria yang tertutup banyak pula yang terjangkau oleh program tersebut

2. Pemberian informasi mengenai program pemeriksaan HIV/AIDS sebagai salah satu program mendeteksi dini sebaiknya diberikan secara tepat, kreatif, dan menarik, baik dari sisi materi maupun dari sisi metode penyampaiannya, dan berkelanjutan

3. Penyuluhan mengenai HIV/AIDS kepada waria perlu dilakukan secara intensif dan tepat sasaran sehingga waria menyadari bahwa perilakunya merupakan perilaku yang beresiko.

4. Diadakan pembinaan dan pelatihan terhadap tenaga kesehatan dan petugas lapangan secara berkala, sehingga tenaga kesehatan dan petugas lapangan mampu menyebarkan informasi mengenai adanya pelayanan pemeriksaan HIV/AIDS.

C. Bagi bidang penelitian

Penelitian ini memiliki beberapa keterbatasan karena dalam penelitian ini menggunakan data sekunder dengan desain studi potong lintang (cross sectional). Untuk mendapatkan hasil yang lebih akurat dan lebih memperlihatkan model keputusan pemeriksaan HIV/AIDS diperlukan penelitian lebih lanjut dengan menggunakan data primer dan dengan menggunakan desain studi yang lebih tepat, misalkan dengan kasus kontrol. Perlu adanya penelitian lebih lanjut mengenai beberapa faktor-faktor yang mempengaruhi keputusan pemeriksaan HIV/AIDS 
sehingga dapat diketahui lebih baik dan lebih detail mengenai faktor-faktor yang mempengaruhi keputusan pemeriksaan HIV/AIDS.

\section{REFERENSI}

Ariyanto, Triawan R (2012). Hak Kerja Waria Tanggung Jawab Negara, Jakarta : Arus Pelangi

Budimulja Unandar. Daili S.F. (2007) Human Immunodeficiency Virus (HIV) dan Aquired Immune Defficiency Syndrome (AIDS) dalam Ilmu Penyakit Kulit dan Kelamin hal 427432. Jakarta: FKUI

Hidaya Nur, Ngatimin M.R., Rachman W.A., Interaksi Sosial Waria terhadap Pelayanan Kesehatan di Kota Makassar. Departemen PKIP Fakultas Kesehatan Masyarakat Universitas Hasanuddin

Kemenkes (2013). Buku Manual Aplikasi Sistem Informasi HIV-AIDS dan IMS. Jakarta: Ditjen PP \& PL.

Kemenkes. (2013) Modul Pelatihan Intervensi Perubahan Perilaku Tahun 2009. Jakarta: Ditjen $P P \& P L, 2010$.

Kementerian Kesehatan RI (2011) STBP 2011: Surveilans Terpadu Biologis dan Perilaku. Jakarta: Direktorat Jenderal Pengendalian Penyakit dan Penyehatan Lingkungan.

Kementrian Kesehatan RI (2011). Panduan Penanggulangan AIDS. Jakarta: Ditjen PP\&PL.

Kementrian Kesehatan RI (2013). Pedoman Penerapan Terapi HIV pada Anak. Jakarta: Kemeterian Kesehatan Republik Indonesia, 2013.

Kementrian Kesehatan RI (2013). Pedoman Umum STBP MARS 2013 TOT. Jakarta: Ditjen PP \& PL.

Kementrian Kesehatan RI (2013). Peraturan Menteri Kesehatan Republik Indonesia Nomor 21 Tahun 2013 Tentang Penanggulangan HIV dan AIDS. Jakarta: Kemnterian Kesehatan.

Kementrian Kesehatan (2013).STBP Pada Kelompok Berisiko Tahun 2013. Jakarta: Ditjen PP $\& P L$.

Komisi Nasional Indonesia untuk UNESCO (2009). Pendidikan Pencegahan HIV. Jakarta: Kementerian Pendidikan Nasional Republik Indonesia.

Lestari K R., Eks-PSK Waria Katolik tangani isu intoleransi. http://indonesia.ucanews.com/2013/12/16/eks-psk-waria-katolik-tangani-isu-intoleransi/ (25 Maret 2015)

Murtiastutik, Dwi (2008) Buku Ajar Infeksi Menular Seksual. Fakultas Kedokteran Universitas Airlangga. Rumah Sakit Umum Dr. Soetomo Surabaya. Airlangga University Press: Surabay

Notoadmodjo (2010), S. Ilmu Perilaku. Jakarta: Rineka Cipta.

Notoadmodjo, S (2007).. Promosi Kesehatan dan Ilmu Perilaku. Jakarta: Rineka Cipta.

Notoadmodjo, Soekidjo (2003). Pendidikan dan Perilaku Kesehatan. Jakarta: Rineka Cipta. STBP (2011). Jakarta: Ditjen PP \& PL, 2011.

USAID (2013). UNDP. Hidup Sebagai LGBT di Asia: Laporan Nasional Indonesia. Tinjauan dan Analisa Partisipatif tentang Lingkungan Hukum dan Sosial bagi Orang dan Masyarakat Madani Lesbian, Gay, Biseksual dan Transgender (LGBT). USAID. UNDP.

USAID (2013). UNDP. Hidup Sebagai LGBT di Asia: Laporan Nasional Indonesia. Tinjauan dan Analisa Partisipatif tentang Lingkungan Hukum dan Sosial bagi Orang dan Masyarakat Madani Lesbian, Gay, Biseksual dan Transgender (LGBT). USAID. UNDP. 